\title{
Use of stable isotopes and trace elements to determine harvest composition and wintering assemblages of belugas at a contemporary ecological scale
}

\author{
Ève Rioux ${ }^{1,2}$, Véronique Lesage $^{1,2,3, *}$, Lianne Postma $^{4}$, Émilien Pelletier ${ }^{1}$, \\ Julie Turgeon ${ }^{3}$, Robert E. A. Stewart ${ }^{4}$, Gary Stern $^{4}$, Mike O. Hammill ${ }^{1,3}$
}

\author{
${ }^{1}$ Maurice Lamontagne Institute, Fisheries and Oceans Canada, Mont-Joli, Québec G5H 3Z4, Canada \\ ${ }^{2}$ Institut des Sciences de la Mer de Rimouski, Université du Québec à Rimouski, Rimouski, Québec G5L 3A1, Canada \\ ${ }^{3}$ Département de Biologie, Université Laval, Québec, Québec G1V 0A6, Canada \\ ${ }^{4}$ Freshwater Institute, Fisheries and Oceans Canada, Winnipeg, Manitoba R3T 2N6, Canada
}

\begin{abstract}
Stable isotopes and trace elements reflect interactions between individuals and their environment over shorter periods than genetic tracers and may capture contemporary patterns relevant to stock conservation and management. The endangered eastern Hudson Bay (EHB) belugas Delphinapterus leucas and those from the non-endangered western Hudson Bay (WHB) population are harvested during migration through Hudson Strait (HS), making protection of the endangered stock difficult. We assessed whether chemical tracers of beluga feeding ecology, i.e. carbon and nitrogen isotope ratios and concentrations of 27 trace elements, can help delineate wintering assemblages and successfully define summering stocks and their relative contributions to aboriginal harvests in HS. Skin was obtained from 1032 belugas in 9 regions of Hudson Bay, HS and southeast Baffin Island from 1989 to 2009. Isotopic signatures and trace element concentrations varied regionally and seasonally and suggest that several summering stocks and at least 3 winter assemblages exist. The use of isotopically defined summering stocks as sources in a discriminant function analysis indicates that the endangered EHB belugas account for 20 to $49 \%$ of the southern HS fall harvest. Low misclassification rates $(\leq 10 \%)$ when using haplotypes unique to, or typical of, EHB belugas as a validation indicate that the isotopic approach is reliable. The analysis combining isotopes with trace elements is promising, although sample size is currently too small to define summering stocks. Spring signatures suggest that Cumberland Sound belugas winter in a separate area and may be differentiated from belugas found elsewhere in southeast Baffin Island, a contemporary pattern relevant to management.
\end{abstract}

KEY WORDS: Stable isotope $\cdot$ Trace element $\cdot$ Beluga $\cdot$ Stock $\cdot$ Arctic $\cdot$ Harvest

\section{INTRODUCTION}

An understanding of discontinuities in species distribution is important for effective management and conservation. Resource units, often referred to as stocks, may exist within populations and can usually be managed independently (Ihssen et al. 1981, Stew- art 2008, Cope \& Punt 2009). However, stocks must be defined over scales relevant to ecological sustainability and population resilience when they are defined from the perspective of human removals (i.e. harvest stocks) (Salt \& Walker 2006, Cope \& Punt 2009).

Several methods have been proposed to define stocks (Ihssen et al. 1981, Stewart 2008), with genetic 
approaches currently being the most popular. Genetics defines stocks over evolutionary scales; this approach is relevant for preserving genetic diversity and reducing risks of extinction of lineages (Palsbøll et al. 2007). However, ancestral patterns may no longer persist under existing conditions or selective exploitation (Harris et al. 2002). Chemical tracers such as stable isotopes and trace elements may complement genetics in respect of stock definition as they assess interactions between individuals and their environment over shorter ecological scales. This can be an individual's lifetime or a shorter period, depending on tracers and tissue type (Kjellström \& Nordberg 1978, Newsome et al. 2010). These approaches assume that animals sharing the same food resources and region have tissues with similar isotopic signatures and/or elemental compositions, as levels of these chemical tracers are strongly related to food ingestion in higher vertebrates, and, to a lesser extent, fish (Langston \& Spence 1995, Campbell et al. 2005, Lin et al. 2007, Caut et al. 2009).

In the Canadian eastern Arctic, at least 3 populations of beluga Delphinapterus leucas are recognized based on summering areas and mtDNA sequence variation: Cumberland Sound (CS), western Hudson Bay (WHB), and eastern Hudson Bay (EHB) belugas (Brennin et al. 1997, Brown Gladden et al. 1999, De March et al. 2002, De March \& Postma 2003, see our Fig. 1). All 3 populations are harvested by Inuit for subsistence, and 2 populations (CS and EHB) are considered endangered by the Committee of the Status of Endangered Wildlife in Canada (COSEWIC 2004). Populations are considered equivalent to stocks, as their definition here is based primarily on the human activity of harvesting. The biological relationship of belugas summering in other areas of the Hudson Bay complex, for example, the north coast of Ontario, James Bay (JB), Hudson Strait (HS), Foxe Basin (FB), Frobisher Bay, Ungava Bay (UB), to the recognized stock, and their seasonal migration patterns, including the location of wintering areas, remain poorly understood (Richard et al. 1990, COSEWIC 2004, Richard 2005).

Belugas from EHB and WHB migrate seasonally through HS (Lewis et al. 2009, Luque \& Ferguson 2010) where they are harvested by aboriginal communities. HS is a known wintering area for WHB belugas (Luque \& Ferguson 2010), but possibly also for belugas from other regions of Hudson Bay and from southeast Baffin Island (MacLaren Marex Inc. 1979, Finley et al. 1982, Luque \& Ferguson 2010), but not CS (Stewart 1994, Richard \& Stewart 2009). Genetics data indicate the removal of EHB belugas exclusively from the south shore of HS, and removals of WHB belugas from along both shores (Turgeon et al. 2011), suggesting differences in migratory patterns among stocks. An accurate assessment of removal from the endangered EHB stock, and an understanding of summering, and particularly wintering, assemblages are crucial for meeting conservation objectives and evaluating the degree of mixing among stocks during late winter/spring when mating is expected to occur.

Given the physiography of the Arctic Ocean basin, it is unlikely that belugas from the various stocks occupy areas homogenous in food web structure, carbon sources and geology (Powles et al. 2004). Satellite telemetry and survey data also suggest sex and age differences in habitat use and distribution in this species, at least in summer (Michaud 1993, Richard et al. 2001a, Loseto et al. 2006), which might lead to differential access to food resources (Vladykov 1946). The combination of stable isotope and trace element analyses offers an opportunity to gain insights into habitat use, to identify animals likely sharing common wintering areas, and to assess composition of the seasonal harvests in HS, including contributions from the endangered EHB stock to this harvest.

Animals that are harvested during the spring/fall migration in HS have recently left their overwintering/ summering areas. With a skin turnover rate of approximately 70 to $75 \mathrm{~d}$ in belugas during periods of maximum epidermal proliferation (St. Aubin et al. 1990), skin isotopic signatures primarily reflect diet and habitat use over the last 2 to 3 months. As a result, skin signatures of belugas harvested during the fall and spring in HS should reflect summer and winter feeding, respectively. In this study, skin samples of over 1000 belugas from 9 regions of the Hudson Bay complex were used to characterize wintering assemblages and summering stocks, and to assess their relative contributions to the HS harvest. Our results were compared to those obtained using mtDNA haplotypes unique to, or typical of, the EHB stock (De March \& Postma 2003, Turgeon et al. 2011) in indicating the persistence of ancestral patterns.

\section{MATERIALS AND METHODS}

\section{Sample collection}

Skin was obtained from 1032 belugas sampled from 1989 to 2009 across 9 regions of the Foxe Basin-Hudson Bay complex, including CS in southeast Baffin Island (Fig. 1, Table S1 in the supplement at www.intres.com/articles/suppl/n018p179_supp.pdf). Sampling 


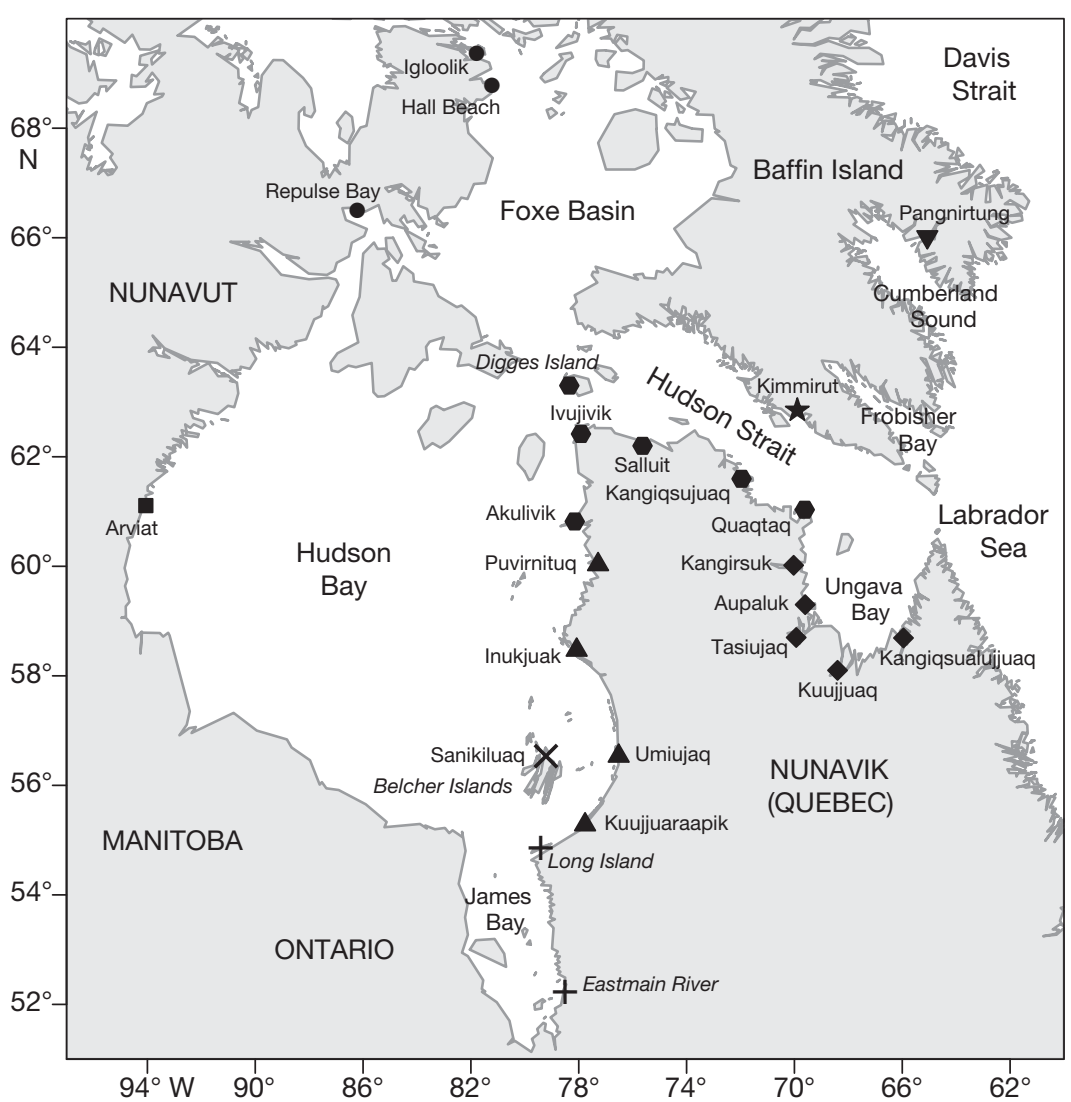

Fig. 1. Study area with regions and communities where belugas were sampled. ( $\mathbf{x}$ ) Belcher Islands; ( $\mathbf{v})$ Cumberland Sound; ( $\mathbf{\Delta})$ Eastern Hudson Bay; $(\bullet)$ Foxe Basin; ( $\star$ ) Hudson Strait North; ( $)$ Hudson Strait South; (+) James Bay; $\bullet$ Ungava Bay; $(\square)$ Western Hudson Bay

locations were restricted to core summering areas where whale abundance is highest to eliminate possible ambiguities as to stock affiliation of sampled animals. Samples came mainly from the aboriginal subsistence harvest, with a few biopsies collected when manipulating animals during satellite telemetry studies. Hunters provided information on harvest date and sector, and a tooth for age determination from dentinal growth layer groups (Stewart et al. 2006). Sex was determined genetically ( $92 \%$ of cases) (Bérubé \& Palsbøll 1996), or in the field. With the exception of JB belugas, which were sampled exclusively in the 2000s, belugas from all of the other regions were sampled both in the 1990s and 2000s.

\section{Chemical analyses}

Stable isotope ratios

Skin samples were preserved frozen $(\mathrm{n}=288)$ or in a dimethyl sulfoxide (DMSO) solution $(20 \% \mathrm{v} / \mathrm{v})$ of deionized water saturated with $\mathrm{NaCl}$ $(\mathrm{n}=744)$. Although DMSO affects carbon $\left(\delta^{13} \mathrm{C}\right)$ and nitrogen $\left(\delta^{15} \mathrm{~N}\right)$ isotope ratios, lipid extraction preceded by water rinsing can restore isotopic signature of marine mammal skin, including that of belugas, as if samples had been frozen directly and lipid-extracted (Lesage et al. 2010). However, $\delta^{15} \mathrm{~N}$ values of cetacean skin are inflated by lipid extraction by ca. $0.2 \%$ and required correction using regressions developed specifically for beluga skin (Lesage et al. 2010).

DMSO-preserved and frozen skin samples $(n=1032)$ were lipid-extracted prior to isotope analyses following Lesage et al. (2010). Briefly, DMSOpreserved samples were rinsed 3 times in distilled water to eliminate some of the DMSO. All samples were then freeze-dried for $24 \mathrm{~h}$ and ground to a fine powder before lipid extraction using a mixture of chloroform and methanol (2:1 v/v) (Folch et al. 1957). After 3 extractions, samples were dried by evaporation, water rinsed, dried overnight at $50^{\circ} \mathrm{C}$ and powdered again. A sub-sample of 0.25 to $0.30 \mathrm{mg}$ of this powder was precisely weighed $( \pm 0.005 \mathrm{mg})$ into a tin capsule and analyzed for stable carbon and nitrogen isotope ratios using an IsoChrom ${ }^{\circledR}$ continuous-flow stable isotope mass spectrometer coupled to a Carlo Erba elemental analyzer (CHNS-O EA1108) (Environmental Isotope Laboratory, University of Waterloo, Ontario). By convention, ${ }^{13} \mathrm{C}$ and ${ }^{15} \mathrm{~N}$ isotope abundances are expressed in delta notation $(\%)$, as $\delta X=\left[\left(R_{\text {sample }} /\right.\right.$ $\left.R_{\text {standard }}\right)-1$ ] $\times 1000$ where $X$ is ${ }^{13} \mathrm{C}$ or ${ }^{15} \mathrm{~N}$, and $R_{\text {sample }}$ is the corresponding ratio ${ }^{13} \mathrm{C}:{ }^{12} \mathrm{C}$ or ${ }^{15} \mathrm{~N}:{ }^{14} \mathrm{~N} ; R_{\text {standard }}$ represents the ratios for the respective standards, i.e. Vienna Peedee Belemnite (PDB) and atmospheric nitrogen (AIR). Replicates using laboratory standards indicated an analytical error of \pm 0.2 and $\pm 0.3 \%$ for $\delta^{13} \mathrm{C}$ and $\delta^{15} \mathrm{~N}$, respectively, whereas the average deviations observed between replicates of skin samples $(n=102)$ were $0.1 \%$ for $\delta^{13} \mathrm{C}$ and $0.2 \%$ for $\delta^{15} \mathrm{~N}$.

Trace element concentrations

Trace element concentrations are affected by DMSO in an unpredictable way (Lesage et al. 2010), 
and thus were determined from frozen samples only, all of which were also analyzed for isotope ratios. The 288 samples were prepared in the same way as for stable isotope analysis. Approximately $0.08 \mathrm{~g}$ of powdered tissue and $6 \mathrm{ml}$ of $\mathrm{HNO}_{3}$ (ultrapure, Seastar Chemical) were transferred to a pre-weighted Teflon reactor (XP-1500 plus) and heated at maximum power for $30 \mathrm{~min}$ in a laboratory microwave oven. The use of a closed system improved digestion and the high temperatures ensured that volatile elements were retained. The 27 trace elements $(\mathrm{V}, \mathrm{Cr}, \mathrm{Fe}, \mathrm{Ni}, \mathrm{Cu}, \mathrm{Be}$, $\mathrm{Na}, \mathrm{Mg}, \mathrm{Al}, \mathrm{Ca}, \mathrm{Mo}, \mathrm{Ag}, \mathrm{Cd}, \mathrm{Sb}, \mathrm{Ba}, \mathrm{Tl}, \mathrm{Pb}, \mathrm{Bi}, \mathrm{U}, \mathrm{Mn}$, $\mathrm{B}, \mathrm{Li}, \mathrm{K}, \mathrm{Zn}, \mathrm{Sn}, \mathrm{Se}, \mathrm{Ti})$ were analyzed using an inductively coupled plasma/mass spectrometer (ICP/MS DRC II Perkin Elmer Health Sciences). Precision and accuracy of the method were assessed using certified reference materials (Bovine muscle NIST-8414, Bovine liver NIST-1577b) and duplicate analyses of 60 random skin samples. Detection limits were obtained from samples of low value or blank samples and were $0.001 \mathrm{\mu g} \mathrm{g}^{-1}$ for all trace elements except $\mathrm{Mn}$ and B $\left(0.002 \mu \mathrm{g} \mathrm{g}^{-1}\right)$, Li and $\mathrm{K}\left(0.003 \mu \mathrm{g} \mathrm{g}^{-1}\right), \mathrm{Zn}$ and $\mathrm{Sn}$ $\left(0.005 \mu \mathrm{g} \mathrm{g}^{-1}\right)$, Se $\left(0.007 \mathrm{ug} \mathrm{g}^{-1}\right)$ and Ti $\left(0.009 \mu \mathrm{g} \mathrm{g}^{-1}\right)$. Concentrations are reported as $\mu \mathrm{g} \mathrm{g}^{-1}$ dry weight.

\section{Data analysis}

HS was divided into HS south (HSS) and north (HSN) to more adequately reflect the expected differential access of these communities to EHB belugas (Fig. 1). The community of Akulivik was assumed to be part of HSS, given that the harvest occurs mainly in the fall, and likely included beluga from both EHB and other stocks. Summer sampling sites were grouped into 7 summering areas, including those for 3 recognized stocks $(\mathrm{EHB}, \mathrm{WHB}$, and $\mathrm{CS})$ and 4 areas occupied by belugas of unknown stock affinity, i.e. Belcher Islands (BI), JB, FB, and UB. When unavailable, sampling location was identified as that of the community reporting the catch because harvest activities generally occurred nearby. Samples with missing sampling location that were obtained from EHB and UB communities after 2000 were excluded from the analysis because these communities were forced to hunt regularly in other regions after that date due to regional allocations and closures.

Seasons were defined as spring (15 Apr-7 Jul), summer (15 Jul-7 Sep), and autumn (15 Sep-30 Nov) based on sightings data in HS and summering areas, and seasonal peak harvest periods (MacLaren Marex Inc. 1979, Hammill \& Lesage 2009). Too few winter samples (1 Dec-14 Apr) were available to be in- cluded in the present analysis. Considering the 2 to 3 mo turnover for beluga skin (St. Aubin et al. 1990), spring signatures likely reflect the last few weeks spent in the wintering area and in early migration, whereas summer samples reflect the last part of the spring migration and summer feeding. Fall samples, which are taken approximately from early October to mid-November, also reflect mostly summer feeding, given that the fall migration is rapid, lasting about 10 $\pm 12 \mathrm{~d}$ and beginning around 16 Oct $\pm 18 \mathrm{~d}$ for EHB belugas (Bailleul et al. 2012).

The ability to identify summer stocks contributing to the HS fall harvest was examined using discriminant function analyses (DFA), first using stable isotopes alone (i.e. $\delta^{13} \mathrm{C}$ and $\delta^{15} \mathrm{~N}$ ) to maximize sample size, then using a reduced set of individuals with both trace element and isotopic data. A principal components analysis (PCA) with VARIMAX rotation was used to examine correlations and reduce the number of trace element variables to a set of uncorrelated factors for input into the DFA and for statistical analyses. Group-specific probability densities in the DFA were calculated using the $k$-nearest neighbours non-parametric approach (data not multinormal). The model was iteratively run with different $k$ values to select the one minimizing overall misclassification rate (De March \& Postma 2003). Misclassification rates were estimated by cross-validation, i.e. by recomputing discriminant functions (DFs) while leaving out the one observation to be classified. Cutting scores in the classification step were unweighted for differences in sample size among summering groups to reduce the likelihood of misclassifying these endangered belugas as non-EHB animals, the groups with the largest sample sizes (Hair et al. 1995).

The DFs defining summering groups were used to assess the origin of belugas harvested in the fall, and estimate relative contributions of the various stocks to the harvests in HSS and HSN. Given that the inclusion of improbable sources may bias modeling results, only the 5 summering stocks most likely contributing to the HS fall harvest were included in the model: $\mathrm{BI}, \mathrm{EHB}, \mathrm{FB}, \mathrm{JB}$ and WHB. Animals harvested in UB, i.e. south of $60^{\circ} \mathrm{N}$, during summer were excluded as a potential source for the fall harvest because UB is east of the locations where samples were collected during the fall, and the fall migrations generally proceed eastwards (Finley et al. 1982, Smith 2006, Lewis et al. 2009). While belugas may occasionally be seen in HS or other parts of the Hudson Bay complex during summer, they were not considered as potential sources for the fall harvest, given their rarity or low abundance. CS belugas were also 
excluded, based on satellite telemetry, Inuit traditional knowledge, and contaminant and isotopic data, which suggest that they remain within this region throughout the year (COSEWIC 2004, De March et al. 2004, Richard \& Stewart 2009). Individual assignments based on chemical tracers were compared to those performed using mtDNA haplotypes that are unique to (H17), or typical of (H18), the EHB stock (De March \& Postma 2003, Turgeon et al. 2011). Individuals were initially assigned to the summering area with the highest probability of assignment, regardless of its value; thereafter we used probability thresholds of 60 and, for the third analysis, $80 \%$.

Insights into wintering assemblages were gained from the comparison of spring harvests in various summering areas, including JB, BI, EHB, UB, and CS. The absence of a spring harvest in WHB and FB prevented the inclusion of these regions in the spring analysis.

The SAS programming language (SAS Institute 1990) and R package (R Development Core Team 2009) were used for statistical analyses. Possible temporal trends in isotopic signatures were tested separately for each summer region using simple linear regressions. Variability among regions in seasonal beluga availability (and harvest) resulted in unbalanced designs and precluded the use of 3-way MANOVA or ANOVAs to simultaneously examine effects of season, sex and region on stable isotope ratios and trace element concentrations (as PCA factors). As a result, multiple 1- or 2-way MANOVAs or ANOVAs were used instead to examine regional patterns, while controlling for type I error using a global $\alpha=0.05$. Analyses of variance were repeated using ranks when assumptions for parametric tests were violated (Conover 1980). Statistically significant ANOVAs were explored for significant pairwise comparisons using post-hoc Tukey's studentized range (HSD) tests and $\alpha=0.05$.

\section{RESULTS}

\section{Sex, regional and seasonal variations}

$$
\text { Stable isotopes }
$$

None of the summer regions showed a trend in beluga $\delta^{13} \mathrm{C}$ or $\delta^{15} \mathrm{~N}$ values over the $20 \mathrm{yr}$ of sampling (linear regressions, all $\mathrm{p}>0.05$ ). However, isotope ratios varied among regions (2-way ANOVA: $F_{8,1014}=$ 50.8 and 66.7 for $\delta^{13} \mathrm{C}$ and $\delta^{15} \mathrm{~N}$, respectively, both $\mathrm{p}<$
0.0001) (Fig. 2, Table S1). Based on Tukey's HSD tests $(p=0.05)$, beluga $\delta^{13} \mathrm{C}$ values were the lowest in $\mathrm{JB}$ and $\mathrm{BI}$, intermediate in CS and HSN, and the most enriched in HSS, WHB, UB, F B and EHB. Values for $\delta^{15} \mathrm{~N}$ were lower in belugas from JB, BI, EHB, HSS and UB compared to those from HSN, CS, WHB and FB.

Carbon and nitrogen isotope ratios varied between sexes (2-way ANOVA on ranks: $F_{1,1014}=10.6$ and 35.8 for $\delta^{13} \mathrm{C}$ and $\delta^{15} \mathrm{~N}$, respectively, both $\mathrm{p}<0.0001$ ), and in a similar way among regions (interaction non-significant). Values were generally higher in males than females for both isotopes. Differences were small $(<0.5 \%)$, but were statistically significant in CS and $\mathrm{BI}$ in the case of $\delta^{13} \mathrm{C}$ values, and in WHB, UB, and BI in the case of $\delta^{15} \mathrm{~N}$ values (Tukey's HSD tests, with $\alpha=$ 0.05 ; Table S1). Given this weak but consistent trend, and the need for the highest possible discrimination power among summer stocks when classifying the HS fall harvests, males and females were treated separately in subsequent analyses.

The seasonal distribution of harvest differed among regions (Table S1), making statistical testing for seasonal effects possible only for males and 3 regions, BI, EHB and UB ( $\mathrm{n} \geq 2$ for all 3 seasons). Both $\delta^{13} \mathrm{C}$ and $\delta^{15} \mathrm{~N}$ values varied seasonally (2-way ANOVA on ranks, $F_{2,168}=6.1$ and 9.6 for $\delta^{13} \mathrm{C}$ and $\delta^{15} \mathrm{~N}$, respectively, both $\mathrm{p}<0.01$ ) (Table $\mathrm{S} 1$ ), but significantly only for BI belugas. Seasonal trends were insignificant when considering each region separately (2-way ANOVA on ranks, p > 0.05 for all comparisons).

Spring isotopic signatures reflect winter habitat use, and varied according to region of harvest (1-way ANOVA on ranks, 6 regions used, all $\mathrm{p}<0.001$ ). Belugas were distributed among 3 main clusters, suggesting the existence of at least 3 wintering assemblages (Fig. 3). Male and female belugas harvested in the spring in CS were isotopically different from those harvested in BI, and belugas from these 2 groups segregated isotopically from those harvested at the same time in EHB, HSN, HSS and UB (post-hoc Tukey's HSD tests, with $\mathrm{p}=0.05$ ). JB belugas were intermediate in signature between the 3 groups and close to belugas from BI, but there were too few individuals, one of each sex, to test for their significance as a separate group.

\section{Trace elements}

A PCA reduced the 27 trace element variables plus $\delta^{13} \mathrm{C}$ and $\delta^{15} \mathrm{~N}$ values to 9 factors (eigenvalues 


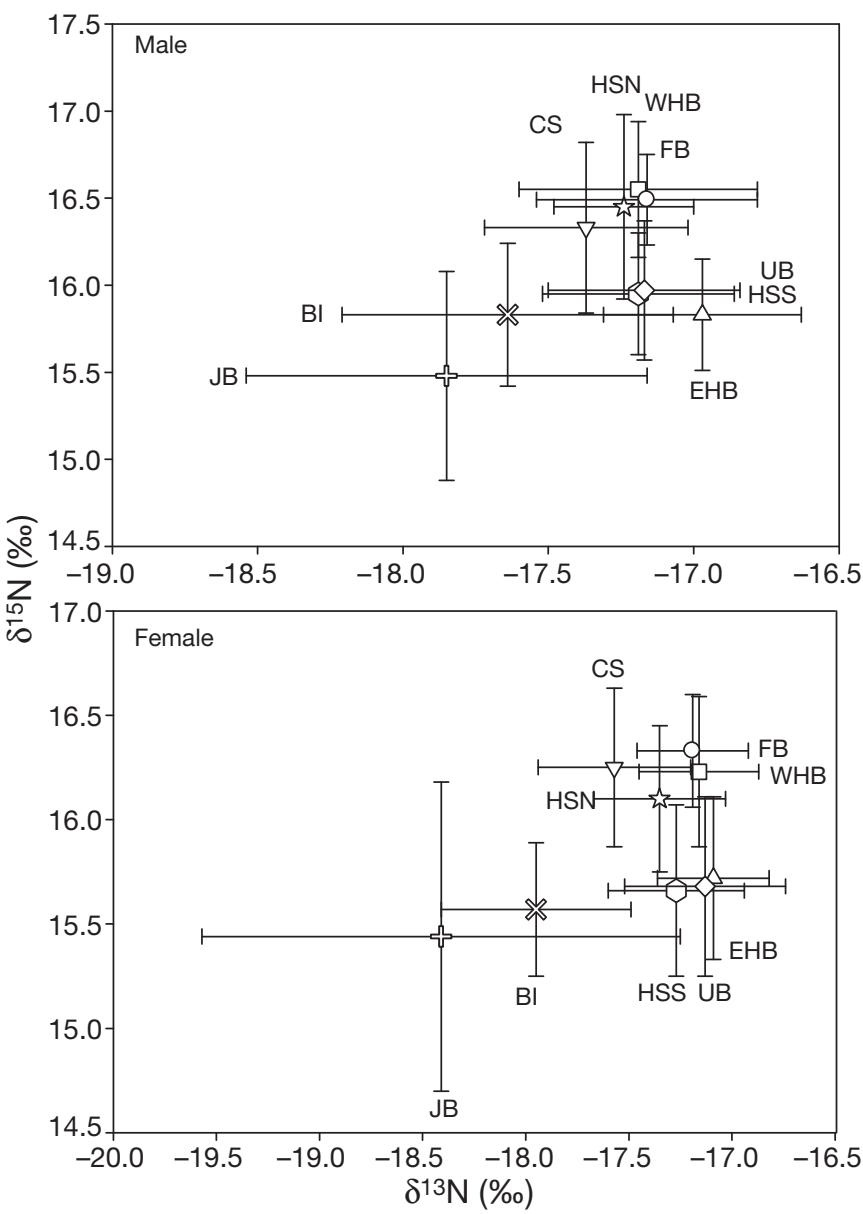

Fig. 2. Delphinapterus leucas. Mean isotopic signatures $( \pm \mathrm{SD})$ of male and female belugas harvested in various locations of the eastern Canadian Arctic. BI: Belcher Islands $(\mathbb{X})$, CS: Cumberland Sound $(\nabla)$, EHB: Eastern Hudson Bay $(\Delta)$, FB: Foxe Basin (O), HSN: Hudson Strait North (㞼, HSS: Hudson Strait South (口), JB: James Bay (§), UB: Ungava Bay $(\diamond)$, WHB: Western Hudson Bay $(\square)$

$>1$ ), revealing strong correlations among sets of variables while retaining $76 \%$ of variance (Table 1). Patterns in trace element concentrations were observed among regions $\left(\right.$ MANOVA, $F_{72,2088}=9.72$, $\mathrm{p}<0.0001$ ) and between sexes within regions (sex: $F_{9,254}=2.26, p=0.019$ ). Sex differences came exclusively from Factor 3, which was dominated by stable isotopes.

Regional effects were observed for a majority of trace elements (1-way ANOVA, $p<0.0005$ for all factors) except those associated with Factors 4 and 9 (i.e. $\mathrm{Cu}, \mathrm{Sn}$ and $\mathrm{Ag}$ ). JB and HSS belugas were strikingly different in trace element signatures compared to belugas from other regions. JB belugas, which were all sampled during summer, were characterized by high concentrations of $\mathrm{V}, \mathrm{Cr}, \mathrm{Fe}, \mathrm{Mn}$, $\mathrm{Ni}, \mathrm{Mo}, \mathrm{Na}, \mathrm{Al}, \mathrm{Li}, \mathrm{Ti}$ and the lowest concentrations

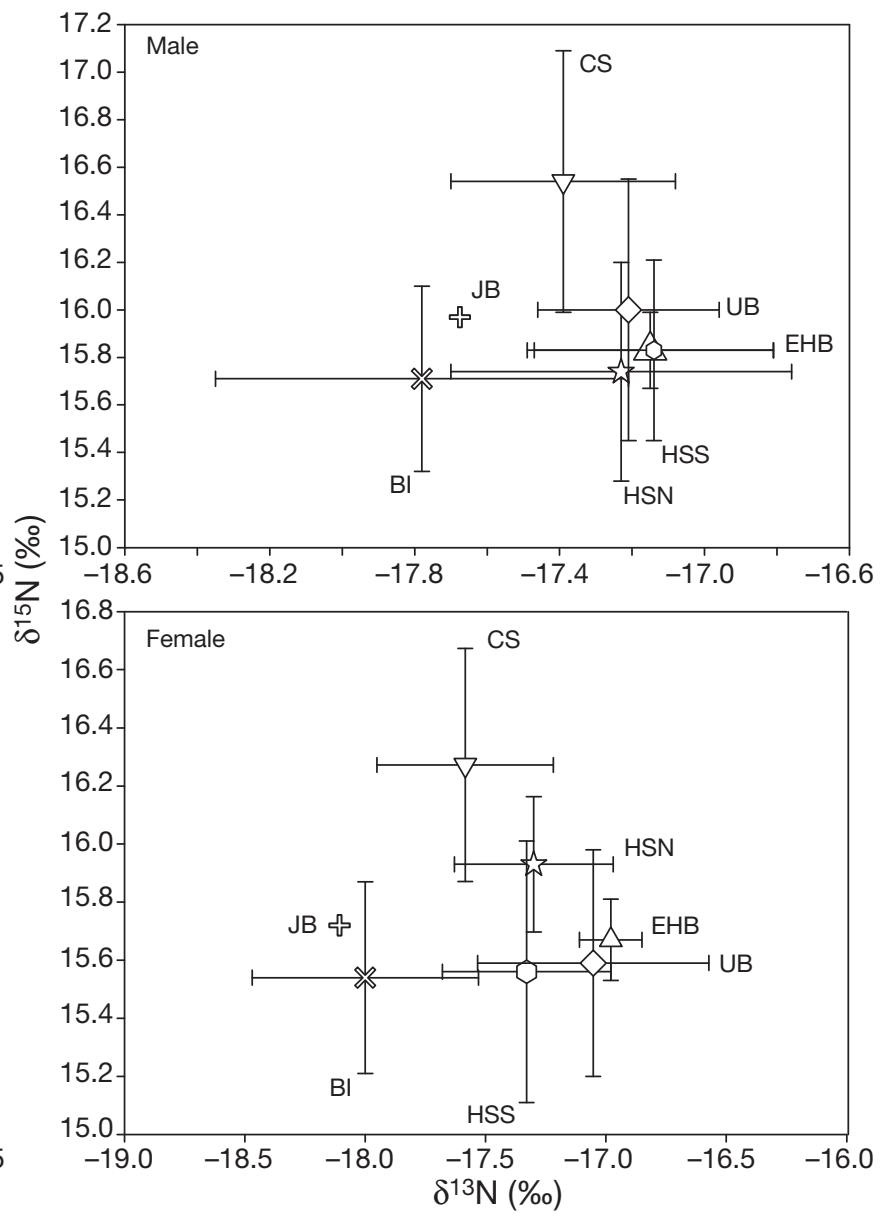

Fig. 3. Delphinapterus leucas. Mean isotopic signatures $( \pm \mathrm{SD})$ of male and female belugas harvested in the spring in various locations. Symbols as in Fig. 2

of $\mathrm{Zn}$ and Se, and thus scored high on Factor 2 and Factor 6, and low on Factor 3 compared to other groups (post-hoc comparisons, all significant at $\mathrm{p}=$ 0.05) (Table S2 in the supplement at www.intres.com/articles/suppl/n018p179_supp.pdf). Belugas from HSS, which were predominantly $(78 \%)$ taken in the spring, showed the highest concentrations of $\mathrm{Se}, \mathrm{Ti}, \mathrm{Li}$ and scored high on Factor 6, and had high levels of all 5 elements associated with Factor $1(\mathrm{U}, \mathrm{Tl}, \mathrm{Sb}, \mathrm{Cd}, \mathrm{Be})$. Belugas harvested in this region are known to come from a mixture of stocks based on genetic data, but their trace element signatures did not resemble any of the summer stocks from Hudson Bay. HSS belugas were most similar isotopically to UB belugas, which comprised an equal mixture of spring and summer samples and scored high on Factors 1 and 6 (post-hoc Tukey's test, NS). Seasonal effects within regions could not be tested statistically due to small seasonal sample sizes (Table S2). 
Table 1. VARIMAX-rotated component analysis factor (F) matrix

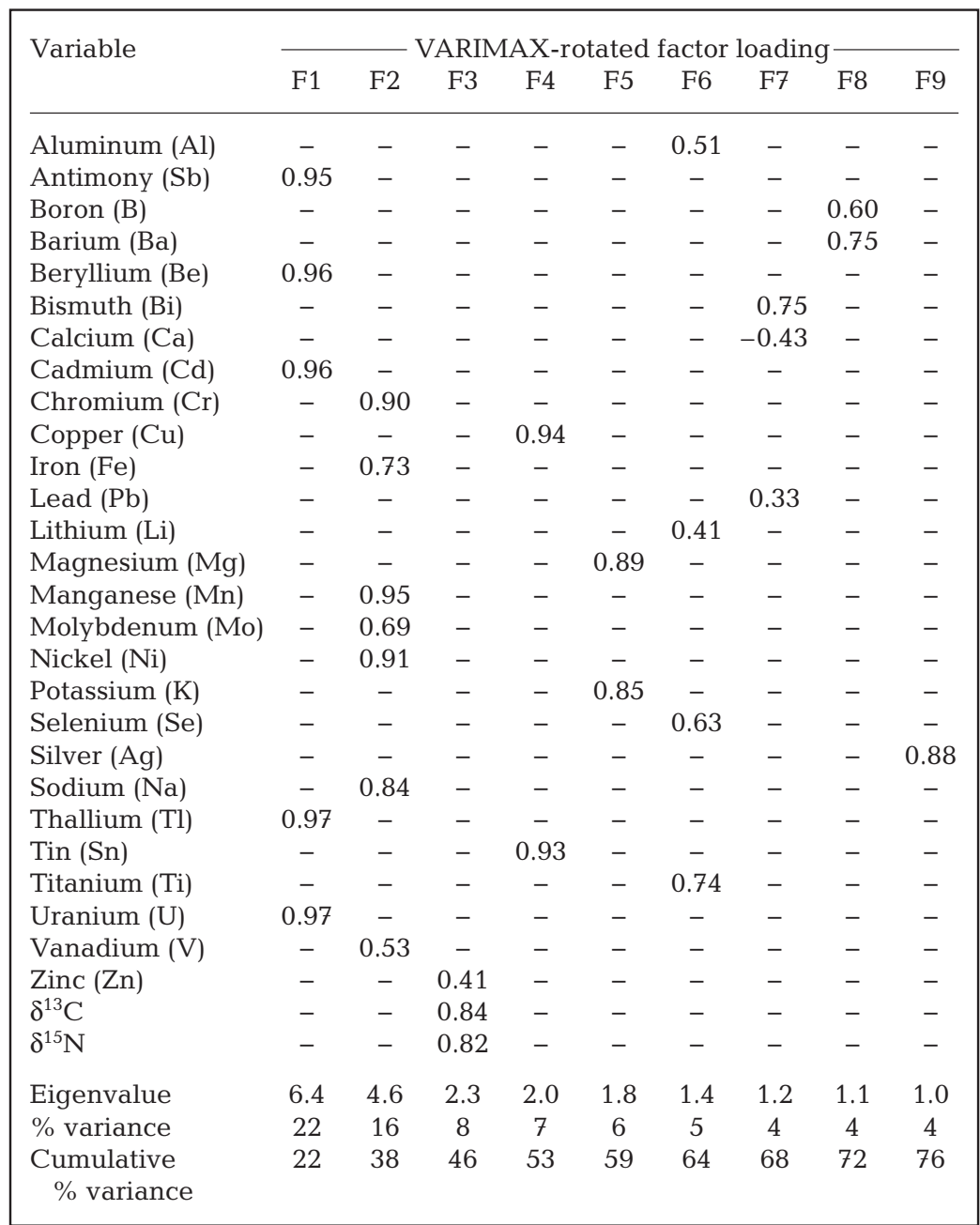

The DFA using 5 nearest neighbors to estimate probability densities and define summering groups correctly classified $83 \%$ of males and $78 \%$ of females to their putative summer groups (Table 2). Chances of errors between classes most likely contributing to the harvest, i.e. EHB and WHB\&FB were $10 \%$ or less, except for female WHB\&FB which had a $22 \%$ chance of being confounded with EHB belugas. A classification of the HS fall harvest using DFs from summering stocks indicated that EHB accounted for half $(49 \%)$ of the HSS harvest, or $41 \%$ males and $60 \%$ females (Table 3 ). When setting a minimum probability for accepting a classification as EHB, contributions from this stock decreased to $37 \%$ (25 and $53 \%$ for males and females, respectively) and 20\% (14 and $28 \%$ for males and females, respectively) for threshold probabilities increasing from 60 to $80 \%$.

The same approach applied to the HSN fall harvest suggests that the latter is constituted mostly (30 of 33 ind.) of WHB\&FB belugas. Raising the probability threshold to 60 or $80 \%$ for acceptance of a beluga as originating from EHB reduced the EHB stock contribution to 1 ind. (3\%). Several males harvested in the fall in HSN had $\delta^{15} \mathrm{~N}$ values higher than those from any of

\section{Stock structure of the HS harvest}

The composition of the fall harvest in HS was first assessed using an isotope-only, sex-specific DFA to determine the discrimination power of isotopes alone, while exploiting the larger dataset. Belugas from BI and JB were indistinguishable isotopically (post-hoc pairwise comparisons, all p > 0.05 for both isotopes) and thus were combined in the DFA analysis and will be referred to as BI\&JB. A similar pattern was observed for belugas from WHB and FB, which were also combined as WHB\&FB in the DFA analysis. Belugas from EHB and those from WHB and FB had similar carbon signatures, but the former had depleted $\delta^{15} \mathrm{~N}$ values compared to WHB and FB belugas and so were considered as a separate source, resulting in a 3-source DFA model, i.e. EHB, BI\&JB, and WHB\&FB (Fig. 4). the summer stocks considered (Fig. 4). Although trends were not as clear for females, values were in the upper range of those possible for nitrogen. These belugas might have come from a summer area unaccounted for in the analysis.

A second classification of summering stocks using a DFA and the reduced dataset with both isotopes and trace element variables correctly classified $95 \%$ of cases ( $\mathrm{n}=82$ out of 86 ) to 1 of 3 summer regions (JB, EHB or WHB; sample sizes for BI and FB were too small to be included in this analysis) (Table 4). While the error rate for EHB belugas was substantial (3 of 6 EHB belugas being confounded with WHB animals), no beluga from any other group was misclassified as EHB, indicating that EHB contributions to the harvest represent a lower bound. Applying the DFs from summer groups to the 24 belugas with isotope and trace element data that were harvested in HS during the fall, it was estimated that 8 of 9 belugas in HSS came 


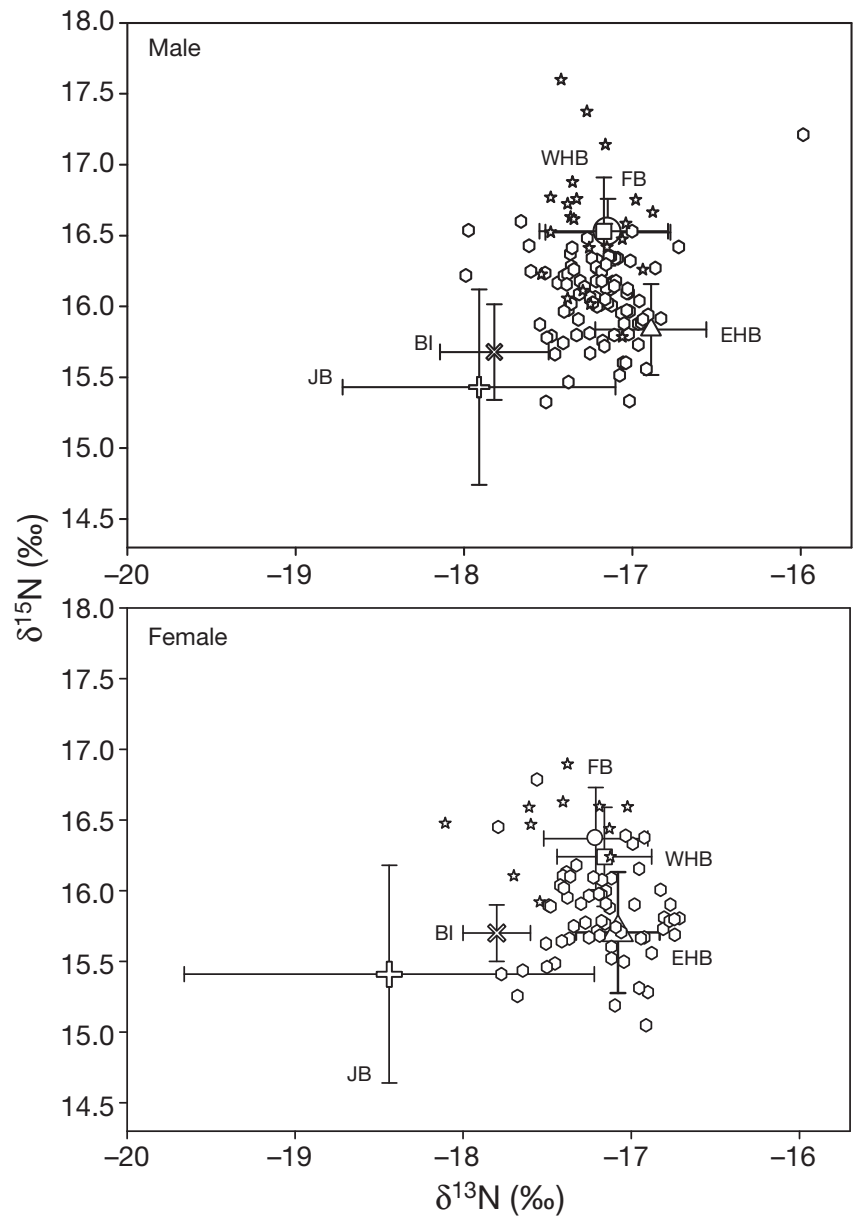

Fig. 4. Delphinapterus leucas. Mean $( \pm \mathrm{SD})$ carbon and nitrogen isotope ratios for the fall harvest in Hudson Strait South ( $\square$ ) and Hudson Strait North (䜣) and for groups summering in various locations of the eastern Canadian Arctic. Symbols as in Fig. 2

from EHB (with one from WHB), whereas 1 of 15 belugas in HSN came from EHB and the rest from WHB.

\section{DISCUSSION}

Isotope ratios revealed patterns which suggest differences in habitat use among belugas from the same region. Differences were generally small, but males were consistently enriched in ${ }^{13} \mathrm{C}$ and ${ }^{15} \mathrm{~N}$ relative to females from the same region, a pattern consistent with that observed for belugas elsewhere (Lesage et al. 2001). Although some of the ${ }^{13} \mathrm{C}$ enrichment of males over females probably relates to their higher $\delta^{15} \mathrm{~N}$ values and trophic positions, it suggests a greater dependency of males either on benthic or nearshore resources (France 1995). In other populations, such as the Beaufort Sea and the St Lawrence
Table 2. Cross-validated classification for summer harvest in various regions of Hudson Bay using linear discrimination functions based on $\delta^{13} \mathrm{C}$ and $\delta^{15} \mathrm{~N}$ values. EHB: eastern Hudson Bay; BI: Belcher Islands; JB: James Bay; WHB: western Hudson Bay; FB: Foxe Basin; n: no. of individuals

\begin{tabular}{|ccccc|}
\hline \multirow{2}{*}{ Sex (n) } & \multirow{2}{*}{ Origin } & \multicolumn{3}{c|}{ \% classification (n) } \\
\cline { 3 - 5 } & & EHB & BI\&JB & WHB\&FB \\
\hline Female & & & & \\
31 & EHB & $87(27)$ & $3(1)$ & $10(3)$ \\
13 & BI\&JB & $0(0)$ & $85(11)$ & $15(2)$ \\
50 & WHB\&FB & $22(11)$ & $8(4)$ & $70(35)$ \\
Male & & & & \\
43 & EHB & $81(35)$ & $12(5)$ & $7(3)$ \\
25 & BI\&JB & $8(2)$ & $80(20)$ & $12(3)$ \\
72 & WHB\&FB & $6(4)$ & $8(7)$ & $85(61)$ \\
\hline
\end{tabular}

Table 3. Contribution of various summering stocks to the Hudson Strait fall harvest as determined from a linear discrimination functions analysis based on $\delta^{13} \mathrm{C}$ and $\delta^{15} \mathrm{~N}$ values. HSS: Hudson Strait South; HSN: Hudson Strait North; other regions as in Table 2. n: no. of individuals

\begin{tabular}{|cccccc|}
\hline \multirow{2}{*}{ Region } & \multirow{2}{*}{ Sex } & $\mathrm{n}$ & \multicolumn{3}{c|}{ \% classification (n) } \\
\cline { 4 - 6 } & & & EHB & BI\&JB & WHB\&FB \\
\hline HSS & Female & 61 & $60(36)$ & $1(1)$ & $39(24)$ \\
& Male & 87 & $41(35)$ & $9(8)$ & $51(44)$ \\
HSN & Female & 11 & $0(0)$ & $9(1)$ & $91(10)$ \\
& Male & 22 & $9(2)$ & $0(0)$ & $91(20)$ \\
\hline
\end{tabular}

Table 4. Cross-validated classification for summer harvest in various regions of Hudson Bay using linear discrimination functions based on factor scores derived from a principal components analysis using 27 trace elements and $\delta^{13} \mathrm{C}$ and $\delta^{15} \mathrm{~N}$ values as input variables (regions as in Table 2)

\begin{tabular}{|c|c|c|c|c|c|}
\hline \multirow[t]{2}{*}{ Origin } & \multirow[t]{2}{*}{$\mathrm{n}$} & \multicolumn{3}{|c|}{$\%$ classification (n) } & \multirow[b]{2}{*}{ WHB } \\
\hline & & Other & EHB & JB & \\
\hline EHB & 6 & - & $50(3)$ & - & $50(3)$ \\
\hline JB & 9 & $11(1)$ & - & $89(8)$ & - \\
\hline WHB & 72 & - & - & - & $100(72)$ \\
\hline
\end{tabular}

Estuary beluga, females and not males appear to be those making greater use of nearshore shallow waters (Michaud 1993, Barber et al. 2001, Loseto et al. 2006), possibly for accrued protection from predators or greater access to food for juveniles with limited diving capacities (Martin et al. 2001). While a sex/age segregation similar to that documented in the Beaufort Sea and the St Lawrence Estuary might exist in Hudson Bay and CS belugas, isotopic data alone were insufficient to identify such a sex/age difference in habitat use in our study. 
The naturally occurring markers we examined represent diets, hence different feeding areas, and differences among groups of whales indicate that belugas are occupying, and feeding in, different areas. Carbon isotope ratios were particularly consistent with basin physiography and water mass movements documented in the eastern Arctic (Powles et al. 2004, Saucier et al. 2004). The ${ }^{13} \mathrm{C}$-depletion of belugas from $\mathrm{JB}$ and $\mathrm{BI}$ probably resulted from the strong influx of ${ }^{13} \mathrm{C}$-depleted freshwater into JB, which spills into southeastern Hudson Bay and the BI area. The Foxe Basin-Hudson Bay complex, which includes HS and UB, receives waters of high salinity and likely has food webs that are typically more marine. Accordingly, belugas from these regions had the highest $\delta^{13} \mathrm{C}$ values. Freshwater inputs are not as strong in the Baffin Bay-Davis Strait ecoregion, leading to intermediate $\delta^{13} \mathrm{C}$ values in belugas from this area, i.e. CS and HSN.

Regional patterns in $\delta^{15} \mathrm{~N}$ values were harder to interpret as they are strongly influenced by diet, local productivity, and regional nitrogen sources and availability (Montoya 2007). A higher productivity has been reported for FB and eastern Baffin Island (CS) compared to Hudson Bay (Powles et al. 2004), possibly contributing to regional differences in $\delta^{15} \mathrm{~N}$, and to the relative enrichment for belugas from CS and FB. Regions where belugas had the most depleted $\delta^{15} \mathrm{~N}$ values (JB, BI, EHB and UB) were those where freshwater runoffs and riverine inputs of nitrate or ammonia were the most intense (Powles et al. 2004, St-Laurent et al. 2011). Whether observed patterns in beluga $\delta^{15} \mathrm{~N}$ values among regions resulted from the animals' usage of nitrogen sources with different characteristics or consumption of prey from different trophic positions, or from similar trophic positions but more productive food webs, cannot be determined.

Trace elements also contributed to regional differentiation among groups. The relatively high concentrations of several trace elements in JB belugas, including $\mathrm{V}, \mathrm{Cr}, \mathrm{Fe}, \mathrm{Mn}, \mathrm{Ni}, \mathrm{Mo}, \mathrm{Na}, \mathrm{Al}, \mathrm{Li}, \mathrm{Ti}$, probably arose from natural geochemistry as well as from industrial inputs (Loring 1976, Gong et al. 1977). This area receives substantial freshwater discharges from rivers originating in the heavily industrialized part of central Canada, which are in some cases also regulated via hydroelectric dams. Similarly, although we did not statistically examine single elements, the order of magnitude higher levels of cadmium documented in belugas from HSS and UB may have arisen from local geochemistry (Painter et al. 1994, Outridge et al. 1997), as cadmium natural abundance is generally greater in marine ecosystems compared with freshwater and terrestrial environments (Outridge et al. 1994). Several marine mammals from this region also show elevated liver Cd levels (reviewed in Outridge et al. 1994, Wagemann et al. 1996), supporting the existence of a regional source with elevated cadmium concentration, most probably from rivers eroding the Canadian Shield, which is known for its substantial deposits of metals. Geochemistry affects marine mammals through diet, and diets vary in their transfer of elements to the marine mammals. Cadmium strongly bioaccumulates in cephalopods (Bustamante et al. 1998), and also attains high concentrations in squid consumers such as narwhals Monodon monoceros and pilot whales Globicephala melas (Wagemann et al. 1983, Caurant \& AmiardTriquet 1995). The absence of high cadmium concentrations in belugas from Hudson Bay, and the fact that most belugas from HSS were sampled in the spring while on their migration back from their wintering areas, suggests that cephalopods may be more important in their diets during winter and while outside of Hudson Bay, than during summer or for those belugas which remain in Hudson Bay year-round. These observations also suggest that the turnover of cadmium and possibly other trace elements in skin is much faster than the 10 to $30 \mathrm{yr}$ established from other tissues (Friberg et al. 1974, Kjellström \& Nordberg 1978), emphasizing the usefulness of this tissue as an archive for seasonal habitat use.

Two independent studies (Stavros et al. 2007, Bryan et al. 2007) examined trace element concentrations in skin of bottlenose dolphins Tursiops truncatus. Both studies found trace elements in skin a useful tool to monitor dolphin populations, as geographical location appeared to be a more important factor than other biological factors (age, sex) to explain differences in trace element concentrations. In addition, a significant correlation for total mercury in skin and liver of stranded and free-ranging dolphins was recently reported (Stavros et al. 2011), suggesting that skin can be useful in predicting mercury concentrations in the liver of free-ranging dolphins. Such a correlation is also an indication of a fast turnover of mercury and possibly other metals in marine mammal skin.

Spring isotopic signatures also provided indications for the existence of at least 3 main wintering areas. One could be located in southern Hudson Bay, as evidenced by the limited seasonal movements documented for JB belugas using satellite telemetry (Bailleul et al. 2012); repeated anecdotal ice entrapments of belugas near the Belcher Islands (Freeman 
1967, Richard 1993, Heide-Jørgensen et al. 2002, Lewis et al. 2009); Inuit traditional knowledge studies reporting beluga wintering at the floe edge near the Belchers (Stewart \& Lockhart 2005). Although the sample size for JB was small in our study, the similarity of belugas from this region with those from BI is consistent with them overwintering either together or close to each other.

The ${ }^{15} \mathrm{~N}$ enrichment of belugas sampled in CS during spring relative to those sampled elsewhere in the same period suggests that they occupy a distinct wintering area. The location of this wintering area cannot be ascertained based on isotope ratios, but the body size differences between belugas summering in $\mathrm{CS}$ and those known to winter in HS indicate that it is unlikely to be HS (Stewart 1994). The limited satellite telemetry data, and Inuit traditional knowledge suggest instead that it is most probably located near the entrance to the Sound (Richard \& Stewart 2009).

The similarity in spring isotopic signatures of EHB and UB belugas suggests similarity in the characteristics of their wintering areas. According to recent telemetry data, the main wintering area for EHB belugas is the Labrador Sea, but includes eastern HS off the Ungava Bay (Lewis et al. 2009, Bailleul et al. 2012). Both telemetry and mtDNA data from springsampled belugas suggest that the fraction of the population wintering in HS is small (Turgeon et al. 2011, Bailleul et al. 2012). There is no information on wintering areas for UB belugas. This population, which once numbered several hundreds of animals, was considerably reduced by commercial whaling, and currently numbers less than 100 individuals (DoniolValcroze \& Hammill 2012). The large number of belugas reported in UB and in HS during winter (Finley et al. 1982) suggest that this represents a 4th wintering area which is used by at least part of the WHB beluga population, as indicated by satellite telemetry data (Luque \& Ferguson 2010). Some individuals from WHB end up in UB as they contribute to the spring harvest there (Turgeon et al. 2011). The absence of a spring harvest in WHB did not allow for the isotopic characterization of this stock and, thus, comparison with belugas wintering elsewhere.

\section{Stock structure of the HS harvest}

A recent study using mtDNA suggested that CS belugas comprise 26 to $32 \%$ of the spring harvest in the HS (Turgeon et al. 2011). The depletion of $\delta^{15} \mathrm{~N}$ in spring HSS belugas relative to CS animals, and their similarity to EHB and UB belugas, makes it improbable that CS belugas contribute significantly to the spring harvest in HSS or UB, although the confidence intervals around mean estimates overlap. There are a number of markers reflecting shorter time scales than genetics which indicate that CS whales do not contribute to HS harvests. Inuit traditional knowledge, satellite telemetry and differences in beluga size between CS, Frobisher Bay and HSN animals all indicate that the CS population is isolated from the HS area (reviewed in De March et al. 2004, see also Kilabuk 1998, Richard \& Stewart 2009, Luque \& Ferguson 2010). In addition, whales harvested in the spring in CS are clearly different than those harvested in HS at the same time (Stewart 1994, our Fig. 3), indicating separate wintering areas.

Successive aerial surveys suggested that Frobisher Bay belugas migrated towards eastern HS and northern UB in the mid-1970s (MacLaren Marex Inc. 1979), and animals from Frobisher Bay are not genetically differentiated from CS belugas (Turgeon et al. 2011). If these migrations still occur, they might explain the detection of CS-type genetic signals in HS (Turgeon et al. 2011, but see De March et al. 2002) and account for the unknown source identified in the fall harvest for HSN. However, summer samples from Frobisher Bay are not available to test the hypothesis of their isotopic similarity with CS animals.

Individual assignments based on chemical tracers were compared to those performed using mtDNA haplotypes that are unique (H17) to, or typical (H18) of, the EHB stock (Turgeon et al. 2011). When defining summer stocks based on stable isotope signatures alone, all but one of the 15 individuals bearing the haplotype H17, unique to EHB, were classified as originating from EHB (i.e. $7 \%$ error rate). Three of 24 were incorrectly classified when considering only those individuals bearing haplotype $\mathrm{H} 18$ that typifies EHB (De March \& Postma 2003). In the case of the fall harvest, mtDNA data for the same sample of 148 individuals that were classified based on isotope ratios indicated a contribution of $18 \%$ from EHB to the HSS harvest when using probabilistic assignments (EHB vs. non-EHB) based on haplotype relative frequencies (De March et al. 2002, B. G. E. de March \& L. D. Postma unpubl. data) and of $23 \%$ when using a genetic mixture analysis (Debevec et al. 2000, Turgeon et al. 2011). Our assignment of $20 \%$ of the HSS harvest $(14 \%$ for males and $28 \%$ for females) using an $80 \%$ threshold probability for assignment is consistent with these estimates. However, misclassification errors were low $(<10 \%)$ even when no threshold was imposed on probability for accepting a classification, suggesting that EHB contribution to the HSS fall harvest probably lies 
between 20 and $49 \%$. Differences may have arisen from methods used for the assessment of EHB contribution, including the reference summer group considered, and a mixed-stock method vs. individual assignment procedure. In a management framework where a stock at risk is involved, the use of a lower level of certainty in assessing identity for the stock of concern may be precautionary. For example, the current management plan in Nunavik allows for a take of 75 belugas in the HSS fall harvest, based on a $20 \%$ contribution of EHB belugas. Using a $60 \%$ threshold probability for assignment to the EHB stock based on isotope ratios raises the contribution of EHB to this hunt up to $37 \%$, and total annual removals from this stock to about 28 whales, i.e. almost double the 15 removals currently assumed.

The proportion of EHB belugas in the HSS fall harvest is relatively large, considering that this population is less than $10 \%$ the size of the WHB population (Hammill et al. 2004, Richard 2005). This, combined with the larger contribution of females to the harvest compared to males (Lesage et al. 2009, present study) suggests a greater tendency of EHB belugas to follow the coastline when migrating (Bailleul et al. 2012, Smith 2006), and more so among females with juveniles than adult males (Kingsley et al. 2001, Martin et al. 2001, Richard et al. 2001b). These observations, combined with a sex/age segregation (Michaud 1993) possibly persisting into the fall migration (Finley et al. 1982, G. J. Colbeck, P. D. Duchesne, L. Postma, V. Lesage, M. O. Hammil, J. Turgeon unpubl. data), may make EHB females more vulnerable to harvesting than males.

In this study, we were able to characterize summering stocks based on their isotopic signatures and assess with good confidence their relative contributions to the fall harvest in HS. In the case of trace elements, however, there is a need for a much larger sample size and better definition of elemental characteristics of summer stocks, particularly for regions other than WHB. Although we were unable to formally test the contribution of animals from Frobisher Bay to the HS harvest, our isotopic results point towards a recent differentiation of these animals from those presumed to be resident in CS, illustrating the power of these elements as sensitive tracers for contemporary changes in stock structures not yet fully captured via genetic studies.

Acknowledgements. We thank Blair Dunn, D. William Doidge and the Society Makivik for organizing the whale sampling program; the hunters for supplying samples; Nunavut Wildlife Management Board Research Trust Fund,
Nunavut Implementation Funds, Fisheries and Oceans Canada, ArcticNet, and International Polar Year for financial support; Yves Morin, Denise Tankula, Sheri Friesen, Brigitte Desrosiers, Claude Potvin, and Pierre Rivard for sample preparation; Yves Clermont and Richard St-Louis for trace element analyses; Thomas Doniol-Valcroze for stimulating discussions and help with figures; Environmental Isotope Laboratory, University of Waterloo for stable isotope analyses, and Brigitte de March for the genetic database.

\section{LITERATURE CITED}

Bailleul F, Lesage V, Power M, Doidge DW, Hammill MO (2012) Differences in diving and movement patterns of two groups of beluga whales in a changing Arctic environment reveal discrete populations. Endang Species Res 17:27-41

Barber DG, Saczuk E, Richard PR (2001) Examination of beluga habitat relationships through the use of telemetry and a geographic information system. Arctic 54:305-316

Bérubé M, Palsbøll P (1996) Identification of sex in cetaceans by multiplexing with three ZFX and ZFY specific primers. Mol Ecol 5:283-287

Brennin R, Murray BW, Friesen MK, Maiers LD, Clayton JW, White BN (1997) Population genetic structure of beluga whales (Delphinaterus leucas): mitochondrial DNA sequence variation within and among North American populations. Can J Zool 75:795-802

Brown Gladden JG, Ferguson MM, Friesen MK, Clayton JW (1999) Population structure of North American beluga whales (Delphinapterus leucas) based on nuclear DNA microsatellite variation and contrasted with the population structure revealed by mitochondrial DNA variation. Mol Ecol 8:347-363

Bryan CE, Christopher SJ, Balmer BC, Wells RS (2007) Establishing baseline levels of trace elements in blood and skin of bottlenose dolphins in Sarasota Bay, Florida: Implications for non-invasive monitoring. Sci Total Environ 388:325-342

Bustamante P, Caurant F, Fowler SW, Miramand P (1998) Cephalopods as a vector for the transfer of cadmium to top marine predators in the north-east Atlantic Ocean. Sci Total Environ 220:71-80

> Campbell LM, Norstrom RJ, Hobson KA, Muir DCG, Backus S, Fisk AT (2005) Mercury and other trace elements in a pelagic Arctic marine food web (Northwater Polynya, Baffin Bay). Sci Total Environ 351-352:247-263

Caurant F, Amiard-Triquet C (1995) Cadmium concentration in pilot whales Globicephala melas: source and potential hazard to the species. Mar Pollut Bull 30: 207-210

Caut S, Angulo E, Courchamp F (2009) Variation in discrimination factors $\left(\Delta^{15} \mathrm{~N}\right.$ and $\left.\Delta^{13} \mathrm{C}\right)$ : the effect of diet isotopic values and applications for diet reconstruction. J Appl Ecol 46:443-453

Conover WJ (1980) Practical nonparametric statistics. 2nd edn. John Wiley \& Sons, New York, NY

- Cope JM, Punt AE (2009) Drawing the lines: resolving fishery management units with simple fisheries data. Can J Fish Aquat Sci 66:1256-1273

COSEWIC (Committee on the Status of Endangered Wildlife in Canada) (2004) COSEWIC assessment and update status report on the beluga whale Delphinapterus leucas in Canada. COSEWIC, Ottawa 
De March BGE, Postma LD (2003) Molecular genetic stock discrimination of belugas (Delphinapterus leucas) hunted in eastern Hudson Bay, Northern Quebec, Hudson Strait, and Sanikiluaq (Belcher Islands), Canada, and comparisons to adjacent populations. Arctic 56:111-124

De March BGE, Maiers LD, Friesen MK (2002) An overview of genetic relationships of Canadian and adjacent populations of belugas (Delphinapterus leucas) with emphasis on Baffin Bay and Canadian eastern Arctic populations. NAMMCO Sci Publ 4:17-38

De March BGE, Stern GA, Innes S (2004) The combined use of organochlorine contaminant profiles and molecular genetics for stock discrimination of white whales (Delphinapterus leucas) hunted in three communities on southeast Baffin Island. J Cetacean Res Manag 6: 241-250

Debevec EM, Gates RG, Masuda M, Pella J, Reynolds J, Seeb W (2000) SPAM (Version 3.2): Statistics Program for Analysing Mixtures. J Hered 91:509-510

Doniol-Valcroze T, Hammill MO (2012) Information on abundance and harvest of Ungava Bay beluga. Can Sci Advis Sec Res Doc 2011:1-12

Finley KJ, Miller GW, Allard M, Davis R, Evans CR (1982) The belugas (Delphinapterus leucas) of northern Quebec: distribution, abundance, stock identity, catch history and management. Can Tech Rep Fish Aquat Sci 1123: $1-57$

Folch J, Lees M, Stanley GHS (1957) A simple method for the isolation and purification of total lipids from animal tissues. J Biol Chem 226:497-509

France RL (1995) Carbon-13 enrichment in benthic compared to planktonic algae: foodweb implications. Mar Ecol Prog Ser 124:307-312

Freeman MMR (1967) An ecological study of mobility and settlement patterns among the Belcher Island Eskimo. Arctic 20:154-175

Friberg L, Piscator M, Nordberg G, Kjellström T (1974) Cadmium in the environment. 2nd edn. CRC Press, Cleveland, $\mathrm{OH}$

Gong H, Rose AW, Suhr NH (1977) The geochemistry of cadmium in some sedimentary rocks. Geochim Cosmochim Acta 41:1687-1692

Hair JF, Anderson RE, Tatham RL, Black WC (1995) Multivariate data analysis: with readings. 4 th edn. Prentice Hall, Upper Saddle River, NJ

Hammill MO, Lesage V (2009) Seasonal movements and abundance of beluga in northern Quebec (Nunavik) based on weekly sightings information. Can Sci Advis Sec Res Doc 2009:1-14

Hammill MO, Lesage V, Gosselin JF, Bourdages H, De March BGE, Kingsley MCS (2004) Evidence for a decline in northern Quebec (Nunavik) belugas. Arctic 57: 183-195

Harris RB, Wall WA, Allendorf FW (2002) Genetic consequences of hunting: What do we know and what should we do? Wildl Soc Bull 30:634-643

Heide-Jørgensen MP, Richard PR, Ramsay M, Akeeagok S (2002) Three recent ice entrapments of Arctic cetaceans in West Greenland and the eastern Canadian High Arctic. NAMMCO Sci Publ 4:143-148

> Ihssen PE, Booke HE, Casselman JM, McGlade JM, Payne NR, Utter FM (1981) Stock identification: materials and methods. Can J Fish Aquat Sci 38:1838-1855

Kilabuk P (1998) Final report on a study of Inuit knowledge of the Southeast Baffin beluga. Prepared for the South- east Baffin beluga management committee, Nunavut Wildlife Management Board, Iqaluit

Kingsley MCS, Gosselin S, Sleno GA (2001) Movements and dive behaviour of belugas in northern Quebec. Arctic 54: 262-275

Kjellström T, Nordberg GF (1978) A kinetic model of cadmium metabolism in the human being. Environ Res 16:248-269

Langston WJ, Spence SK (1995) Biological factors involved in metal concentrations observed in aquatic organisms. In: Tessier A, Turner DR (eds) Metal speciation and bioavailability in aquatic systems. John Wiley \& Sons, Chichester, p 407-478

Lesage V, Hammill MO, Kovacs KM (2001) Marine mammals and the community structure of the Estuary and Gulf of St Lawrence, Canada: evidence from stable isotope analysis. Mar Ecol Prog Ser 210:203-221

Lesage V, Baillargeon D, Turgeon S, Doidge DW (2009) Harvest statistics for beluga whales in Nunavik, 2005-2008. Can Sci Advis Sec Res Doc 2009:1-25

> Lesage V, Morin Y, Rioux È, Pomerleau C, Ferguson SH, Pelletier É (2010) Stable isotopes and trace elements as indicators of diet and habitat use in cetaceans: predicting errors related to preservation, lipid extraction and lipid normalization. Mar Ecol Prog Ser 419:249-265

Lewis A, Hammill MO, Power M, Doidge DW, Lesage V (2009) A comparison of eastern Hudson Bay (Delphinapterus leucas) movement and aggregation patterns using satellite telemetry and Nunavik traditional ecological knowledge. Arctic 62:13-24

> Lin SH, Chang CW, lizuka Y, Tzeng WN (2007) Salinities, not diets, affect strontium/calcium ratios in otoliths of Anguilla rostrata. J Exp Mar Biol Ecol 341:254-263

> Loring DH (1976) Distribution and partition of cobalt, nickel, chromium, and vanadium in the sediments of the Saguenay fjord. Can J Earth Sci 13:1706-1718

> Loseto LL, Richard P, Stern GA, Orr J, Ferguson SH (2006) Segregation of Beaufort Sea beluga whales during the open-water season. Can J Zool 84:1743-1751

Luque SP, Ferguson SH (2010) Age structure, growth, mortality, and density of belugas (Delphinapterus leucas) in the Canadian Arctic: responses to environment? Polar Biol 33:163-178

MacLaren Marex Inc (1979) Report on aerial surveys of birds and marine mammals in the southern Davis Strait between April \& December, 1978. Vol. III. Prepared for Esso Resources Canada Ltd., Aquitaine Co. of Canada Ltd. and Canada Cities Services Ltd., Arctic Petroleum Operators Association. Project No.146

Martin AR, Hall PA, Richard PR (2001) Dive behaviour of belugas (Delphinapterus leucas) in shallow waters of western Hudson Bay. Arctic 54:276-283

Michaud R (1993) Distribution estivale du béluga du SaintLaurent; synthèse 1986 à 1992. Rapp Tech Can Sci Halieut Aquat 1906:vi +28

Montoya JP (2007) Natural abundance of $15 \mathrm{~N}$ in marine planktonic ecosystems. In: Michener R, Lajtha K (eds) Stable isotopes in ecology and environmental science, 2nd edn. Blackwell, Malden, WA p 176-201

Newsome SD, Clementz MT, Koch PL (2010) Using stable isotope biogeochemistry to study marine mammal ecology. Mar Mamm Sci 26:509-572

Outridge PM, MacDonald DD, Porter E, Cuthbert ID (1994) An evaluation of the ecological hazards associated with cadmium in the Canadian environment. Environ Rev 2: 91-107 
Outridge PM, Evans RD, Wagemann R, Stewart REA (1997) Historical trends of heavy metals and stable lead isotopes in beluga (Delphinapterus leucas) and walrus (Odobenus rosmarus rosmarus) in the Canadian Arctic. Sci Total Environ 203:209-219

Painter S, Cameron EM, Allan R, Rouse J (1994) Reconnaissance geochemistry and its environmental relevance. J Geochem Explor 51:213-246

Palsbøll PJ, Bérubé M, Allendorf FW (2007) Identification of management units using population genetic data. Trends Ecol Evol 22:11-16

Powles H, Vendette V, Siron R, O'Boyle B (2004) Proceedings of the Canadian marine ecosystems workshop, 23-25 March 2004, Ottawa. DFO Can Sci Advis Sec Proc Ser 2004/016:1-47

R Development Core Team (2009) R: A language and environment for statistical computing. R Foundation for Statistical Computing, Vienna

Richard PR (1993) Status of the beluga, Delphinapterus leucas, in western and southern Hudson Bay. Can Field Nat 107:524-532

Richard PR (2005) An estimate of the western Hudson Bay beluga population size in 2004. Can Sci Advis Sec Res Doc 2005:1-29

Richard PR, Stewart DB (2009) Information relevant to the identification of critical habitat for Cumberland Sound belugas (Delphinapterus leucas). Can Sci Advis Sec Res Doc 2008:1-24

Richard PR, Orr JR, Barber DG (1990) The distribution and abundance of belugas, Delphinapterus leucas, in eastern Canadian subarctic waters: a review and update. In: Smith TG, St.Aubin DJ, Geraci JR (eds) Advances in research on the beluga whale, Delphinapterus leucas. Can Bull Fish Aquat Sci 224:23-38

Richard P, Orr JC, Martin AR (2001a) Summer and autumn movements of belugas of the eastern Beaufort Sea stock. Arctic 54:223-236

Richard PR, Heide-Jørgensen MP, Orr JC, Dietz R, Smith TG (2001b) Summer and autumn movements and habitat use by belugas in the Canadian high Arctic and adjacent areas. Arctic 54:207-222

Salt D, Walker B (2006) Resilience thinking: sustaining ecosystems and people in a changing world. Island Press. Washington, DC

SAS Institute (1990) SAS/STAT users guide, 4th edn. Cary, $\mathrm{NC}$

Saucier FJ, Senneville S, Prinsenberg S, Roy F and others (2004) Modelling the sea ice-ocean seasonal cycle in

Editorial responsibility: Helene Marsh,

Townsville, Queensland, Australia
Hudson Bay, Foxe Basin and Hudson Strait, Canada. Clim Dyn 23:303-326

Smith AJ (2006) Beluga whale (Delphinapterus leucas) use of the Nelson River Estuary, Hudson Bay. MSc dissertation, University of Manitoba, Winnipeg

St. Aubin DJ, Smith TG, Geraci JR (1990) Seasonal epidermal molt in beluga whales, Delphinapterus leucas. Can J Zool 68:359-367

St-Laurent P, Straneo F, Dumais JF, Barber DG (2011) What is the fate of the river waters of Hudson Bay? J Mar Syst 88:352-361

Stavros HCW, Bossart GD, Hulsey TC, Fair PA (2007) Trace element concentrations in skin of free-ranging bottlenose dolphins (Tursiops truncatus) from the southeast Atlantic coast. Sci Total Environ 388:300-315

Stavros HCW, Stolen M, Durben WN, McFee W, Bossart GD, Fair PA (2011) Correlation and toxicological inference of trace elements in tissues from stranded and free-ranging bottlenose dolphins (tursiops truncatus). Chemosphere 82:1649-1661

Stewart REA (1994) Size-at-age relationships as discriminators of white whales (Delphinapterus leucas) stocks in the eastern Canadian Arctic. Medd Gronl Biosci 39: 217-225

Stewart REA (2008) Redefining walrus stocks in Canada. Arctic 61:292-308

Stewart DB, Lockhart WL (2005) An overview of the Hudson Bay marine ecosystem. Can Tech Rep Fish Aquat Sci 2586:1-487

Stewart REA, Campana SE, Jones CM, Stewart BE (2006) Bomb radiocarbon dating calibrates beluga (Delphinapterus leucas) age estimates. Can J Zool 84:1840-1852

> Turgeon J, Duchesne P, Colbeck GJ, Postma LD, Hammill MO (2011) Spatiotemporal segregation among summer stocks of beluga (Delphinapterus leucas) despite nuclear gene flow: implication for the endangered belugas in eastern Hudson Bay (Canada). Conserv Genet 13:419-433

Vladykov V (1946) Etudes sur les mammifères aquatiques, Vol IV. Nourriture du marsouin blanc ou béluga (Delphinapterus leucas) du fleuve Saint-Laurent. Département des Pêcheries, Québec

Wagemann R, Snow NB, Lutz A, Scott DP (1983) Heavy metals in tissues and organs of the narwhal (Monodon monoceros). Can J Fish Aquat Sci 40(Suppl 2):s206-214

- Wagemann R, Innes S, Richard PR (1996) Overview and regional and temporal differences of heavy metals in Arctic whales and ringed seals in the Canadian Arctic. Sci Total Environ 186:41-66

Submitted: February 23, 2012; Accepted: June 11, 2012 Proofs received from author(s): August 15, 2012 